\title{
No LONGER NEWLY ARRIVED - Museum presentations of IMMIGRANT CULTURES IN NATIONS WITH DOMINANT «INDIGENOUS» CULTURES
}

Per B. Rekdal

Since the end of the 1960s Norway - like other Western countries - has had a relatively large number of immigrants from countries outside Europe. This immigration has partly consisted of refugees, partly of people searching for better economic and social conditions. They now constitute a significant part of the permanent population; significant in the sense that they are far more visible than the -until recently-more numerous North European expatriates who have "always" been in the country, and significant because, by the media and politicians and in many peoples minds, "they" have been classified as a single category characterised by unemployment, a range of social problems and deviant religious beliefs. ${ }^{l}$

It follows from this that there is a political aim to activate, include and make equal the immigrants' access to work as well as cultural life - including the museums.

Norwegian museums have over the last few years been increasingly concerned with the recent past and the present. The presence of non-European immigrants in Norway has sufficient historical depth to be of interest to the museums; the immigrants ought in fact to come within the museums' documentation responsibility in relation to their local community or their region.
Very few museums have however dared go into this field, least of all in documentation. Nor have have there been all that many exhibitions on immigrant cultures. Some museums have arranged performances - especially with dance and music sometimes wrapped in patronising politi$\mathrm{cal}$ and romantic rhetoric.

Such performances practically never occur as a regular part of the museum's activities, and obviously the museum staff regard them as more politically than museally important. In fact, the expressed desire to include immigrant culture in the 
116 museums does not generally come from the immigrants themselves. It comes from the Norwegian political establishment and the Norwegian liberal intelligentsia. But if the immigrants themselves do not demand to be included in the museums, why is it so important to get «them» into the museums? A partial answer could be that by including the immigrant cultures in the museums, the majority culture could also include them in one of the most important of their own value hierarchies, thus making the display of cultural difference an expression of an overarching cultural equality. It is believed that this will give the Norwegians a greater appreciation of immigrant cultures ${ }^{2}$, and lead the immigrants themselves to put a higher value to their own cultures. Clearly a political aim, but also a moral aim.

\section{NORWEGIAN MUSEUMS \\ - INDIGENOUS AND \\ NATIONAL MINORITIES}

The overwhelming majority of the Norwegian population are indigenous peoples in the sense that their ancestors cannot be traced to immigrants, either as individuals or as groups. This contrasts with countries like the USA and Australia where the ethos of the nation is largely based on the concept of immigrating to new land.

Additionally, almost all of Norway's 4,5 million inhabitants have a tendency to consider themselves members of a culturally homogenous nation and also to consider that this cultural homogeneity is exceptionally successful - an attitude they probably share with many other nations' inhabitants.
When Norwegians think of themselves as homogenous, they conveniently forget about the Samis who have traditionally lived in the northern and middle part of the country and are also found in Sweden, Finland and Russia. They are an indigenous population, speaking a Finno-Ugrian language, radically different from the Germanic Norwegian language.

They also forget the Finns who migrated from Finland from the 17th to the 19th century and settled in Eastern and Northern Norway as fishermen and farmers.

And they forget gypsies and tinkers (travellers).

They do not, however, forget the newly arrived immigrants from Pakistan, Chile, etc, etc. They disturb the allegedly harmonious picture. I will return to this later.

During the World Exhibition in London in 1851, the University of Oslo exchanged Sami objects for objects from Borneo. This marked the start of the University's ethnographic museum, which opened to the public in 1857. The museum collected objects from Norwegian as well as African peasants, from Sami reindeer pastoralists as well as from ancient Egyptians. At that time it would have been unfair to call it a colonial type of museum, rather it seemed to be governed by an all-embracing curiosity.

Then, in the 1890s the Norwegian Folk Museum was established. This was a new breed of museum - exclusively Norwegian in content and very romantic. It was our first national museum and is still by far the largest. The Ethnographic Museum transferred to this national museum all objects from Norway - except the Sami collections. The Sami was considered a non-Norwegian culture within the borders 
of Norway, a culture more related to ethnic groups in Northern Russia and Siberia. Typically, the curators at the Ethnographic Museum - not having the funds to go to Africa and Asia - went to Northern Norway to study the Samis, their own "primitives».

This created a situation also known in other countries: the Sami objects were classified as belonging to a type of culture, almost a species, beyond time, remaining in a museum with objects from other timeless species of cultures from different parts of the world, while the Norwegian objects were sent to the Norwegian Folk Museum where they were considered to belong to a historical process, or at least classified as belonging to specific historical periods.

Then again, around 1950, something new happened. The Ethnographic Museum got a new director, whose name was Gutorm Gjessing. He initiated the transfer of the Sami objects to the Norwegian Folk Museum. He did not deny that the Sami culture was typologically most closely related to groups in Russia and Siberia, but he said that the Sami objects belonged in the Norwegian Folk Museum because the Sami were as much a part of the Norwegian nation as other peoples in Norway, and our national museum should, as a matter of course, collect and display the cultural variation that existed within the nation. The Norwegian Folk Museum accepted the objects with thanks, but among his anthropological colleagues the decision was controversial.

Gjessing was one of the earliest academics to write about the necessity of a Sami self-consciousness process. The transfer of the Sami objects was very popular among the politically conscious part of the Sami population. In the course of the $1970 \mathrm{~s}$ and -80 s the Sami indigenous rights movement grew stronger and culminated in the establishment in 1993 of an institution called the Sami Parliament (Sametinget).

During this period several Sami local and regional museums were founded and a special association for Sami museums was established. Interestingly, the Sami view of the Ethnographic Museum changed. From being considered a museum with colonial associations, it gradually came to be seen as a museum for the 4th World, a museum for the world's indigenous cultures. When the Samis were again introduced into the Ethnographic Museum's displays in the late 1970s, it was in a global, comparative perspective, and the Samis now considered it positive to be seen as an indigenous culture related to Russian and Siberian indigenous cultures and, in a larger perspective, to be presented in the same museum as American Indians and Australian aboriginals.

In conclusion, the historical process has resulted in the presentation of the Sami in the Norwegian Folk Museum as equal to other parts of Norwegian culture, they have their own local and regional museums, and they are presented as an indigenous population in a global perspective in the Ethnographic Museum. Among these museums, the displays in the Ethnographic Museum and the Norwegian Folk Museum have small sections devoted to the Sami political movement, while the Sami's own presentations, in their local and regional museums, are almost completely non-political. This probably reflects the local character of the museums which 
118 illustrate an internal cultural setting, rather than a situation where marking ethnic borders is relevant. Local Samis may prefer a presentation of their culture which stresses the highly valued decorative arts and their unique adaptation to nature something for them to be proud of and something for the visitors to admire - rather than conflicts. ${ }^{3}$

Typically, the Sami museums and other Sami institutions have been created through their own initiatives, and this is also the pattern for the Finnish ethnic revitalisation; they have recently announced plans for special museums about the Finnish cultures.

A museum for the tinkers ${ }^{4}$ is also under way. As late as the 1950s the Norwegian authorities took children away from tinker parents, sterilised women and even lobotomised some, all in order to exterminate an unwanted culture. The initiative for the museum partly comes from the tinkers' organisation, partly from museum professionals outside the tinker community. The museum is still controversial among the tinkers because some fear that it may result in publication of their tinker ancestry in their local society. Norwegian museum professionals would like to have a section of the museum devoted to the persecution of the tinkers, while the tinkers themselves seem to prefer a display solely devoted to the positive sides of tinker culture.

\section{THE IMMIGRANTS}

The Sami vitalisation movement taught the Norwegian authorities something about processes of ethnicity and minority issues. Thus the Sami have doubtless created a basis of understanding that may be useful in the new multicultural situation.

But the differences are considerable.

The Sami are an indigenous population and the main issues have been connected with rights to land and water resources. Certainly language and other issues are extremely important, but the basic issue was concerned with natural resources. ${ }^{5}$

The immigrants mainly live in towns and cities. They come from many different countries and each group varies considerably in size. Even immigrants from one country of origin are split into several organisations and congregations. They have no primary connection to natural resources, but have a multitude of urban types of professions.

The Sami themselves initiated their museums and actively influenced the presentation of Sami culture in other museums. The immigrants have so far made few such advances and rarely visit museums, even when the museums are displaying exhibitions with objects from their own countries of origin.

This situation will probably change in one way or another, but political pressure is now put on the museums to include what is sometimes called a "multicultural perspective», at other times «immigrant culture» - usually meaning the same thing. And mind you: not immigrant cultures in the plural, but immigrant culture in the singular, as if we are dealing with a category with shared cultural characteristics. This makes it even more important for the museums to sort out what perspectives, and whose interests immigrant cultures in museums are going to deal with.

The questions that could be raised are many. Are the immigrant cultures to be 
"preserved" like other cultures and traditions inside Norway's borders in the form of authoritative versions of Tamil, Pakistani, Chilean, Vietnamese, etc, etc, culture? If the answer is yes, should the museums focus on the traditional culture in the country of origin, buying objects from Pakistan, etc, and bring them to museums in Norway? Or should the museums focus on the traditionalistic objects the immigrants themselves have brought to Norway and perhaps even produce in Norway? We know this form of display of Norwegian culture from exhibitions in the USA, with touching objects so full of uninhibited nostalgia that native Norwegians from Norway today often see them as involuntary parodies.

Or should the museums focus upon the dynamic, changing identities and expressions that immigrants in Norwegian society have lived and live, so hybrid that the term hybrid culture becomes too simple and beside the point? Not to preserve authoritatively, but take care of and remember the very process through the objects and other media.

There is no doubt in my mind that I prefer the latter version. I would find most exciting a museum that reflects the lived realities. But I am not an immigrant. I am a member of the solidly indigenous all-powerful majority.

What if the immigrants themselves want an authoritative display of cultural stereotypes? What if they are so fed up with being connected with social problems and with far-from-perfect daily reality, that they want displayed the most shameless romanticization of their cultures of origin? After all, this is what the Norwegians themselves more or less did when they established their national and regional museums around 1900 .

Of course this is a real possibility. Not necessarily quite to such an extreme as I put it, but still... Allison Arieff in an article in Museum Anthropology claims that the brand new National Museum of the American Indian in New York has become a museum, where American Indians not only display, but, through their curatorial and conservational practices - try to live out romantic conceptions of the perfect Indian culture of the past, "replacing one stereotypical representation with another - homogenising an inherently heterogeneous group of people in the process ${ }^{6}$. She sees the museum as not another kind of preservation, but as another kind of reservation.

The director for the National Museum of the American Indian, Richard West, naturally has another perspective on the museum. He emphasises the importance of "the systematic use of the unfiltered Native Voice... allowing them to speak for themselves through these institutions that have such a definitive role in describing, shaping, and defining their place in American culture.» ${ }^{7}$

I have not visited the National Museum of the American Indian and it is the debate and the principles rather than the real museum that I am now focusing upon.

Arieff explains the state of affairs that she claims to have observed in this museum as resulting from the fact that "the ideology of the dominant group so penetrates into the underprivileged sections of a population that there is no guarantee that the presentation of a self produced by members of the minority population would necessary differ from the empowe- 
120 red group's presentation of otherness». ${ }^{8}$

A related process is known from Norway, where in the 19th century the city's romanticised view of the rural population created stereotypes that were soon taken over by the rurals and kept alive in rural organisations, long after this view had become irrelevant in the cities.

It is however quite possible that Arieff has missed the point the National Museum of the American Indian is trying to make and uses a measuring stick that makes it impossible for her to detect the qualities of the museum that - according to its director - make it a radically new concept. She may simply be asking the wrong questions.

But the issue is nevertheless relevant. Marjorie Halpin writes that a museum's "narrative is at once authoritative and romantic»" and she quotes Duncan: "To control a museum means ... to control the presentation of a community and its highest values and truths.... It is precisely for this reason that museums and museum practices can become objects of fierce struggle and impassioned debate». ${ }^{10}$

One version of these conflicts might be between certain parts of the public wanting through the museums to project a self presentation based on a safe, traditionalistic, static, high status conception on the one side, and on the other side museum professionals who see it as the primary goal of their careers to tear down such (to them) antiquated museum conceptions in order to promote changing, debate-oriented museums.

The disagreement between Arieff and West may be seen as conflicting views about what role the museum should play. West is concerned with «institutions that have a definite role in describing, shaping and defining [the American Indian's] place in American culture ${ }^{11}$, while Arieff points out that the location of the museum in downtown Manhattan should rather have the consequence that «the urban reality of Native populations should have been addressed ${ }^{12}$.

Personally I think both viewpoints may be legitimate, as long as the leaders of a museum fully understand what they are doing and what effect it has. In an establishing phase where respect and recognition are at stake, authoritative and even slightly romanticising presentations may have a desired effect. This approach is not least used by minorities trying to establish their cultural expressions in line with those of the dominant majority. However, if this kind of authoritative presentation is considered obsolete in the majority culture, the effect achieved will certainly be contrary to what is intended.

\section{FEW IMMIGRANT MUSEUMS}

I have so far concentrated on alternative possibilities for mono-cultural presentations of different immigrant cultures in museums.

Now, the reality is that few countries in Northern Europe at present have any large number of museums based on specific immigrant cultures. Self-presentations are so far generally reserved for the established native populations, whether they be minorities or majorities, or old immigrant populations, as is the case with Jewish museums.

The new multicultural situation caused by the recent immigration is normally treated as just that: a multicultural situati- 
on with little emphasis on each culture. Exhibitions and arrangements stress cultural diversity through composite presentations from Chile, Zambia, Pakistan, Vietnam, etc, etc. As indicated at the beginning of this paper, the immigrants' contribution to the cultural diversity of the society is considered by many politicians to be a sort of mono-culture, addressed as «immigrant culture» in the singular.

Almost all political rhetoric in Norway stresses the need to acknowledge and appreciate the multicultural situation and the immigrants as part of - or in themselves constituting - this cultural diversity. This is in marked contrast to how Norwegian and Sami culture is referred to: the weight when speaking of these is almost always on the importance of appreciating them as individual cultures. This difference may be caused by the recent appearance of immigrant cultures, but nevertheless gives an impression of inequality; they are part of a multicultural mosaic, without any individuality other than being examples of the beauty of this mosaic.

To be fair, Norwegian culture is often part of multicultural presentations, and sometimes so also are the Sami, but they can well afford to be part of the multicultural, having a safely recognised position in Norwegian society and a host of other fora where they can display their uniqueness.

To be fair again, multicultural presentations can function extremely well in relation to culturally diverse school classes and other groups that are in themselves small universes which are forced daily to deal with their multiculturality. Such presentations function especially well when relevant comparisons create debate.

Even so, I think the basic problem with multicultural presentations of minority cultures in a majority setting is clearly described by an American Indian who wrote that: "Whites seek to own difference and with this ownership increase their own well-being.. Our difference ... is reduced to playing ... parts in the West's dreams...»." ${ }^{13}$

Typically, the fact that Western artists and craftsmen are inspired by expressions from all parts of the world has never been considered a problem, while artists from Africa, etc. being inspired by the West or East, or whatever, are sometimes said to represent hybrid cultures and their authenticity may be questioned.

Initially my question was why it is important to include immigrant cultures in Norwegian museums when they themselves hardly have asked for this? My answer is that museums basically is about self-presentations, of cultures as well as individuals. This self-presentation can be mine as a museum professional making an exhibition, ours as anthropologists or perhaps historians putting our personal mark on the description and analysis of others, his as an exhibiting Sami artist, or theirs as a group of Pakistanis participating in the documentation about themselves, or hers as a Vietnamese presenting herself through making a display of Norwegian culture - in Norway or Vietnam, or anywhere.

For some the right to present oneself is taken for granted to such an extent that they see themselves and the institution as one and the same, being the case with many museum curators, or being the case with the members of a majority culture "owning» the museums. For others, the opportunity to present oneself in institu- 
122 tions with so much symbolic authority as museums have, may become the difference between introvert self-degradation and extrovert self-pride. For individuals and groups of immigrants - and for the society in which they live - such differences are of major importance.

While museums seldom explicitly are political institutions, their political function must not be ignored. And certainly, museums do have a moral basis, and we are acting from this moral basis all the time, but all too often not reflecting upon it. When confronted with issues like the inclusion of immigrant cultures in museums, the political function and moral basis of the museum should be both acknowledged and accepted, but also controlled. Controlled in the sense that the museum's programs are the result of a selfcritical examination of the role the museum should play, and realistic assumptions about which actions will produce the desired effects.

A moral note at the end: Admiration of others based on self-contempt is destructive, as is contempt for others based on self-admiration. Both are based on fear: Fear of one's own, fear of others. Respect for others is always based on self-respect. This is pretty banal, but as a thumb rule when trying to reach new groups for the museum, it is good to keep at the back of one's head. 


\section{REFERENCES}

Ames, Michael M.: The politics of Difference: Other Voices In a Not Yet Post-Colonial World. Museum Anthropology, vol. 18, no. 3, 1994. American Anthropological Association.

Arieff, Allison: A Different Sort of (P)Reservation: Some Thoughts on the National Museum of the American Indian. Museum Anthropology, vol. 19, no. 2, 1995. American Anthropological Association.

Duncan, Carol: Civilizing Rituals: Inside Public Art Museums, Routledge, London/New York 1995.

Halpin, Marjorie M.: «Play it again, Sam»: reflections on a new museology. Museum International, vol. 49, no. 2, 1997. UNESCO, Paris.

Todd, Loretta: What more do they want? In Indigena: Contemporary Native Perspectives. Editors: G. McMaster and L. A. Martin. Douglas \& McIntyre, Vancouver 1992.

West Jr, Richard W.: The National Museum of the American Indian: Perspectives on Museums in the 21st Century. Museum Anthropology, vol. 18, no. 3, 1994. American Anthropological Association.

\section{NOTES}

1. Based on a paper presented at the ICME (International Committee of Museums of Ethnography)-session of the triennial conference of ICOM (International Council of Museums) in Melbourne, Australia 1998. The paper is indebted to the discussion on native voices in museums in Museum Anthropology as reflected in the reference list. The author is currently engaged by the Norwegian Museum Authority on a project aimed at preparing for the inclusion of immigrant cultures in Norwegian museums.

2. I am purposely using the term "culture» in an extremely simplistic manner.
3. So far, very few repatriation cases have been brought up by the Samis. Two recent examples can be mentioned.

The first case was politically important. After an uprising in 1852 where officials were killed, the leaders were sentenced to death and beheaded. The bodies were buried in their home locality, but the heads were taken to Oslo and included in the University's collection of skeletons and skulls, numbering several thousand. In 1997 the skulls were sent north and buried next to the bodies. In the other case, early in this century a sacred stone was removed by a local vicar and sent to the Ethnographic Museum, later to be transferred to the Norwegian Folk Museum and even displayed in the permanent Sami exhibition. A Sami sacred stone is generally a natural formation often with a special appearance that may be reminiscent of a face or something else. The function of this particular stone was to ensure good fishing in a nearby lake and this was, in fact, also the reason for demanding it back: to improve fishing in the lake. The repatriation was at first treated with discretion, but after a while widely publicised, and I wonder how long it will be before the stone is stolen by souvenir hunters.

The question of using original Sami objects for Sami ceremonies - as is known from America with American Indian ritual objects - has not so far been a topic. Nor has anyone suggested traditional care taking practices as described from the National Museum of the American Indian in USA. Probably such practices would shock the Sami curators and conservators just as deeply as any mainstream conservative Norwegian curator or conservator.

4. I apologise to anyone who feels that the term "tinker» is derogatory and would prefer the term "traveller». "Tinker» is used here because it is most widely understood.

5. Many, perhaps most, of the Samis have occupations not directly related to land and water 
PER REKDAL

124 resources and many live far away from the Sami areas. Nevertheless, rights to land and water are also of basic symbolic importance, and thus embrace all Samis.

6. Arieff 1995 , p. 81.

7. West jr. 1994, p. 54 and 57.

8. Arieff 1995 , p. 81 , here also quoting Dominguez 1987 p. 136.

9. Halpin 1997, p. 53.

10. Duncan 1995 , p. 8-9.

11. West jr. 1994, p. 57.

12. Arieff 1995 , p. 85.

13. Ames 1995 p. 12, referring to Todd 1992, p. 30.

Per B. Rekdal er museumsleder for Universitetets etnografiske museum i Oslo. Fra 1998 er han president $i$ ICME, den internasjonale komiteen for etnografiske (inkl. etnologiske, folkemuseer, etc.) museer innen ICOM.

Adr: Universitetets etnografiske museum,

Frederiksgt. 2, N-0165 Oslo,

Fax: +47-22 859960

Epost:p.b.rekdal@ima.uio.no 